\title{
Milk production and hormonal changes in Murrah Buffaloes administered recombinant Bovine Somatotropin (rBST)
}

\author{
Jyotsna Prasad and Mahendra Singh \\ National Dairy Research Institute, Karnal -132001, Haryana, India
}

\begin{abstract}
Investigation was carried out to determine the influence of short term administration of recombinant bovine somatotropin (rBST) on plasma growth hormone (GH), Insulin like growth factor-I (IGF-I), prolactin (PRL) and milk production of buffaloes in early lactation. Experimental buffaloes received i.v. rBST infusion in jugular vein @ 5mg/hr. i.v. for 5 days, while control group was given placebo injection. Blood samples were collected for 5 consecutive days before, during and after treatment and plasma GH, IGF-I and PRL levels were measured. Administration of rBST increased plasma GH $(P<0.01)$ and IGF-I $(P<0.01)$ concentration simulating to increased milk yield $(P<0.01)$. Milk IGF-I concentration was more after cessation of treatment $(P<0.05)$ than before and during the treatment period. The milk yield increased by $29.9 \%$ during the experiment $(P<0.01)$ in comparison to control. rBST treatment influenced milk protein $(P<0.01)$ and lactose $(P<0.01)$ without affecting plasma glucose and NEFA, milk NEFA, citric acid and fat content. There was no adverse effect of rBST on mammary health and plasma prolactin concentration. The positive correlation of GH and IGF-I with milk yield indicated a galactopoietic effect of both the hormones to augment milk production in buffaloes.
\end{abstract}

Keywords: rBST, hormone levels, buffaloes, milk production and composition, blood metabolite

\section{INTRODUCTION}

Buffalo is the major source of milk production and contributes more than $54 \%$ of annual milk production in India (Hegde, 2006). Bovine somatotropin is a homeiorhetic agent affecting hepatic and adipose tissue (Etherton and Bauman, 1998). Administration of rBST increase milk yield in cows, buffaloes and goats (Ludrt et al., 1989; Etherton and Bauman, 1998; Radchiff et. al., 2000; Helal and Lasheen, 2008). The effect of rBST on milk composition and mastitis incidence are well established (Bauman, 1992; Chalupa et al., 1996). However, effect of intravenous rBST administration on hormones $(\mathrm{GH}$, insulin like growth factor-I, prolactin) in relation to milk production and composition in early lactation has not been reported in buffaloes.

\section{MATERIAL AND METHODS}

Experimental Animals and treatment: Ten Murrah buffaloes in early lactation (16 days) were selected from Institute's buffalo herd and were managed in a loose housing system with brick floor. These were offered ad lib green fodder-berseem (Trifolium alexandrium) while concentrate mixture (70 \% TDN and $21 \%$ CP) was offered based on milk production. Drinking water was available ad lib. to all buffaloes.
Hand milking of buffaloes was carried twice a day in morning and evening and milk yields were recorded. The experimental buffaloes were infused intravenously solution of recombinant bovine somatotropin (rBST, Monsanto; NHPP-NIDDK, LotM010-001), @ 5mg/ animal /day for 5 consecutive days (day 21 to 25 postpartum) in jugular vein through a catheter. The control group buffaloes were given placebo injections.

Collection of Samples and analysis: Jugular blood samples were collected in heparinized tubes at 8:00 A.M daily for 5 consecutive days before $(-5,-4,-3,-2$ -1 day), during (1, 2, 3, 4, 5 day) and after $(+1,+2$, $+3,+4,+5$ day) intravenous infusion of rBST. Milk samples collected at intervals of blood sampling, were analyzed for fat (REMI), protein (Singhal and Desraj, 1989), lactose (Perry and Doon, 1950), nonesterified fatty acids, NEFA (Shipe et al. 1980) and milk IGF-I ( Malven et al. 1987 ). Blood glucose was estimated by the Kit (25940, Span Diagnostics Ltd. GOD/POD). Plasma GH, IGF-I and prolactin were measured by double antibody radioimmunoassay procedures (Singh and Ludri, 2000). Statistical analysis of data was carried out using Least Square Analysis (3- way ANOVA) with interaction (Snedecor and Cochran, 1980). 


\section{RESULTS}

Mean GH and IGF-I levels varied $(P<0.01)$ between days and between group $(P<0.01)$. However, between animal variation for $\mathrm{GH}$ and IGF-I level was non-significant except prolactin which varied $(\mathrm{P}<0.05)$. Plasma GH and IGF-I was higher $(P<0.01)$ in experimental than in control group during and after treatment (Figure 1). Milk yield increased during (29.9\%) and after treatment (19.4\%) concomitant to rise in plasma GH and IGF-I level. Higher plasma $\mathrm{GH}$ and IGF-I levels were observed during the posttreatment period in comparison to control. Milk IGF-I levels was $34.67 \pm 3.48 \mathrm{ng} / \mathrm{ml} \quad(29.68 \pm 4.54$ to $38.10 \pm 3.35 \mathrm{ng} / \mathrm{ml}$ ) before treatment. The IGF-I levels were low during treatment on day 1, 2, 3 but was higher on day 4 and 5 of treatment and continued (Figure 4). However, milk IGF-I level was high $(42.02 \pm 5.22 \mathrm{ng} / \mathrm{ml})$ on day 1 post treatment and declined thereafter. When the data was pooled for three phases of treatment, overall average milk IGF-I levels was non-significantly different.

Fat content of milk of both the group was similar before treatment $(6.88 \pm 0.16$ vs. $6.99 \pm 0.21 \%)$ and increased non-significantly during the treatment (7.04 \pm 0.41 to $7.27 \pm 0.31$ ). The protein content of milk varied $(P<0.01)$ between groups, but between animal and between period variation was non-significant. Lactose varied between groups $(P<0.01)$ and between periods of the study $(P<0.01)$. Milk NEFA concentration non-significantly varied between groups, between animals and between periods of the study. Citric acid content of milk varied between the groups $(P<0.05)$ and was low in experimental buffaloes in comparison to control.

Plasma IGF-I level was positively correlated with plasma glucose, lactose $(P<0.05)$, milk yield and protein $(P<0.01)$. Milk yield, glucose $(P<-0.01)$ and fat $(P<0.05)$ varied between animal. rBST treatment increased protein and lactose content $(P<0.01)$ without any adverse effect on plasma glucose, NEFA, milk NEFA, and fat. Milk yield, protein, lactose $(P<0.01)$ and citric acid $(P<0.05)$ varied between the groups. The variation in milk yield, plasma glucose $(P<0.01)$ and fat between animal was significant $(P<0.05)$. Milk yield was positively correlated to lactose $(P<0.05), \mathrm{GH}$ and IGF-I $(P<0.01)$. Fat was positively correlated with milk NEFA $(P<0.05)$, while milk NEFA was correlated positively with citric acid $(P<0.01)$. Lactose was positively correlated to $\mathrm{GH}$ $(P<0.01)$ and IGF-I $(P<0.05)$.

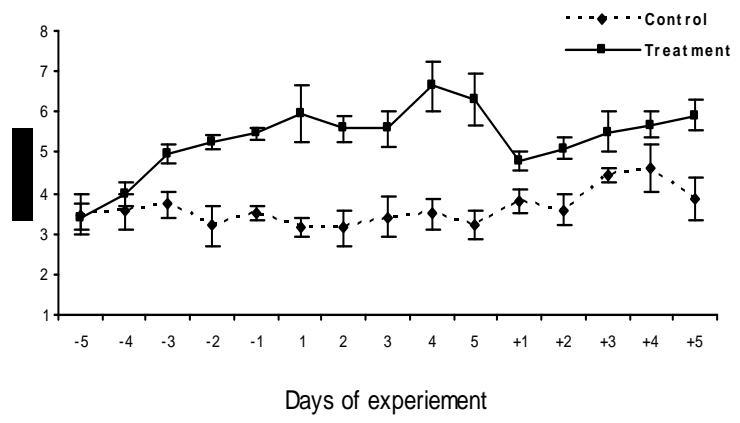

Figure1. Plasma GH levels in Murrah buffaloes administered rBST during early lactation

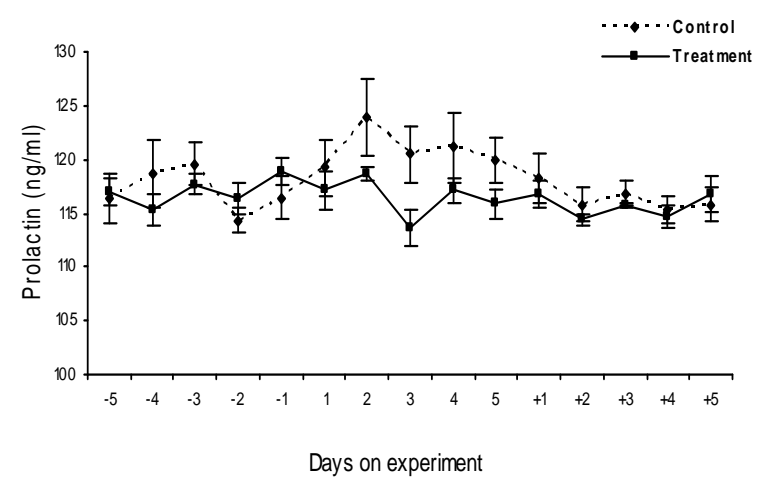

Figure 3.. Plasma prolactin levels in Murrah buffaloes administered rBST during early lactation

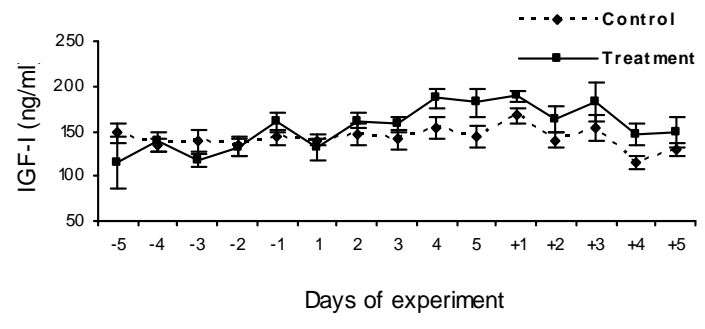

Figure 2.. Plasma IGF-I levels in Murrah buffaloes administered rBST during early lactation

Figure 4. Milk IGF-I concentration before, during and after the administration of $r B S T$.

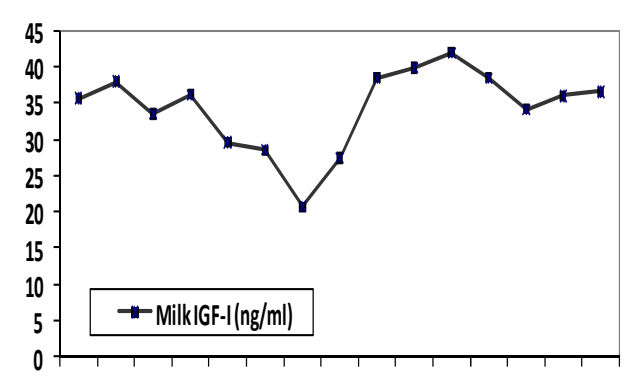

$\begin{array}{lllllllllllllll}-5 & -4 & -3 & -2 & -1 & 1 & 2 & 3 & 4 & 5 & 1 & 2 & 3 & 4 & 5\end{array}$ before during after 


\section{DISCUSSION}

The significant increase in milk production of experimental buffaloes concomitant to elevated $\mathrm{GH}$ and IGF-I levels suggests role of both the hormones in milk secretion of buffaloes in early lactation (Singh and Ludri, 1994). However, varied response of treatment in different buffaloes was attributed to circulating plasma $\mathrm{GH}$ levels in buffaloes (Singh and Ludri, 1994) and cows (Erdman et al., 1999; Chalupa et al., 1996). The significantly higher IGF-I in rBST treated buffaloes on different days, during and after treatment period corroborates that GH act via IGF-I (Winder and Forsyth, 1986; Prosser et al., 1987; Faulkner, 1999). Further, the lag period of IGFI secretion in milk was 3 days and the milk IGF-I levels were still higher as observed by Faulkner (1999) in goats. Conversely cow milk IGF-I concentrations were significantly increased $(P<0.05)$ in comparison to plasma and milk GH concentration for early, mid and late lactation periods (Zhao, et al., 1994). .Administration of rBST in doses of 25 and $50 \mathrm{mg} /$ day i.m. for 14 days increase milk production without affecting fat and protein (Ludri et al., 1989) contrary to increased fat, protein and lactose observed in this study. The reasons of such short term treatment on milk composition of buffaloes require further investigation as milk composition is influenced by energy balance and mobilization of body reserves (Eppard et al., 1985; Peel et al., 1982 and Tyrrell et. al. 1988). Prolactin concentration was not affected by rBST as it has no role in established lactation (Saha and Singh, 1998).

\section{CONCLUSION}

Intravenous administration of rBST increased milk production by increasing plasma $\mathrm{GH}$ and IGF-I $(\mathrm{P}<0.01)$ without change in prolactin level. The effect of rBST was long term and persists five days post- treatment due to higher GH and IGF-I level and lead to higher milk IGF-I concentration. The rBST treatment increase milk protein $(P<0.01)$ and lactose $(P<0.01)$, while plasma glucose and NEFA, milk NEFA, fat and prolactin remain unaffected.

\section{REFERENCES}

Bauman, D. E. Bovine somatotropin: review of an emerging animal technology, J.Dairy Sci. 75: 3432-3451.

Chalupa, W., Vecchaivelli, B., Gallian, D. .,T Ferguson, J. D., Baird, L. S., Hemken, R. W. Harmon, R. W., Harmon, R. J., Soderholm, C. G., Otterby, D. E., Annexstad, R.J., Linn, J.G., Hansen, W.P., Ehla, F.R., Palmquist, D.L. and Eggert, R..G. Response of dairy cows supplemented with somatotropin during weeks 5 through 43 of lactation. J. Dairy Sci.1996, 79: 800-812

Etherton, T.D. and Bauman D.E.Biology of somatotropin growth and lactation of domestic animals. Physiol. Rev.1998 78: 745-761

Eppard P.J. Bauman, D.E., Bitman, J., Wood, D.L. and Akers, R.M. Effects of dose of bovine growth hormone on milk composition: $\alpha$-lactalbumin, fatty acids and mineral elements. Journal of Dairy Sci. 1985 68, 3047-3054.

Erdman, R.A., Sharma, B.K., Shaver, R.D. and Cleale, R.M. Dose response to recombinant BST from weeks 15 to 44 post partum in lactating dairy cows. Journal of Dairy Sci. 1999 73: 2907-2915.
Faulkner, A. Changes in plasma and milk concentrations of glucose and IGF-I in response to exogenous growth hormone in lactating goats. J. Dairy Res.1999 66(2): 207-214.

Hegde, N.G. A challenge to Livestock Industry. Souvenir of the 39 the Annual General Meeting and 48 the National Symposium on "Energising Rural India Compound Livestock Feed Manufactures Association of India (CLFMA), Manesar, Haryana, India, August 26, 2006 Pg. 50-63.

Ludri, R.S. Upadhyay, R.C., Singh, M., Gunevatna, J.R.M. and Basson, R.P. Milk production in lactating buffalo receiving recombinantly produce bovine somatotropin. J. Dairy Sci.1989 72: 2283-2287.

Peel, C.J., Fronk, T.J., Bauman, D.E. and Goreurit,, R.C. Lactational response to exogenous growth hormone and abomsal infusion of a glucose-sodium caseinate mixture in high-yielding dairy cows. J. Nutri.1982 112: 1770.

Prosser, C.G., Fleet, I.R., Hart, I.C. and Heap, R.B. Changes in concentration of insulin like growth factor I (IGF-I) in milk during bovine growth hormone treatment in the goats. J. Endocr.1987 112: 65.

Radchiff, R.P., Vandehar, M.J., Chapin, L.T., Pilbean, T.E., Beede, D.K., Stainsiewski, E.P., and Tucker, H.A. Effect of diet and injection of bovine somatotropin on prepubertal growth and first lactation milk yields of Holstein cows. J. Dairy Sci.2000 83: 23-29.

Shipe, W.F., Senyk, G.F. and Fountain, K.B. Modified copper soap solvent extraction method for measuring free fatty acids in milk. J. Dairy Sci1980 63: 193-198.

Singh, Mahendra and Ludri, R.S. Plasma growth hormone profile and milk yield response of Murrah buffaloes (Bubalus bubalis) treated with slow release formulation of somidobove. Buffalo J.1994 10: 81-84.

Singh, Mahendra and Ludri, R.S. Immediate effect of bromocryptine on plasma hormone concentrations during early lactation in crossbred goats. Small Rum. Res..1999 31:141-147.

Singhal, O.P. and Des Raj New approaches for chemical quality assurance. Indian Dairyman, 1989 41: 43-47.

Snedecor, G.W. and Cochran, W.C. Statistical methods. $7^{\text {th }}$ Edn., Lowa State Univ. Pregs, Ames, Lowa,1980 Page 20-30.

Tyrrell, H..F., Brown, A.C.G., Reynolds, P.J., Haaland, G.L., Bauman, J.E., Peel, C.J. and Steinhour, W.D. Effect of bovine somatotropin on metabolism of lactating dairy cows: energy and nitrogen utilization as determined by respiration calorimetry. J Nutr. 1988 118:1024.

Winder, S. J. and Forsyth, I. A. Insulin like growth factor I (IGFI) is a potent mitogen for ovine mammary epithelial cells. Endocr. 1986 108: 141.

Zhao, X. McBride, B.W., Trouten, R. F. L. M., Golfman, L., Burton, J..H. Somatotropin and insulin like growth factor-I concentrations in plasma and milk after dairy or sustained release exogenous somatotropin administrations. Domestic Anim. Endocr.1994 11(2): 209-216. 